
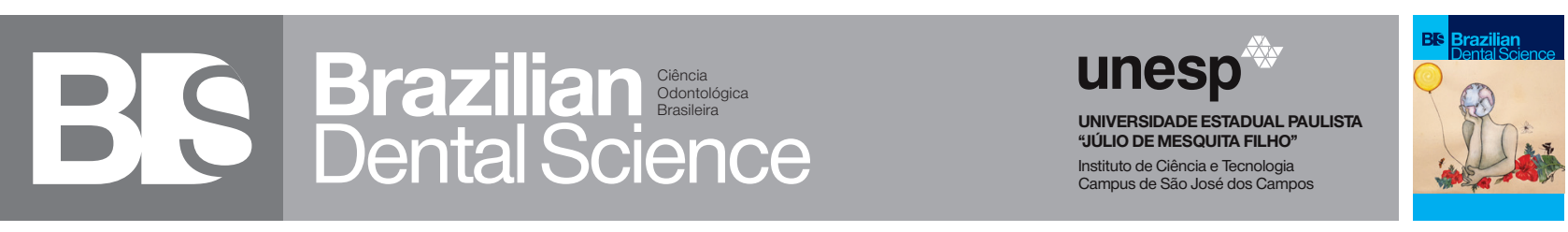

\title{
Wear behavior of monolithic zirconia against natural teeth in comparison to two glass ceramics with two surface finishing protocols: an in-vitro study
}

Comportamento do desgaste da zircônia monolítica frente a dentes naturais em comparação com duas cerâmicas de vidro com diferentes protocolos de acabamento superficial: um estudo in vitro

Dina Kamal ABOUELENIEN ${ }^{1}$, Hany Halim NASR ${ }^{2}$, Hanaa ZAGHLOUL ${ }^{3}$

1- Faculty of Oral and Dental Medicine- Misr International University - Cairo - Egypt.

2- Faculty of Dentistry - Cairo University - Cairo - Egypt.

3- Faculty of Oral and Dental Medicine - Misr International University - Cairo - Egypt.

\begin{abstract}
Objective: To evaluate and compare the wear behavior of three different ceramic systems; monolithic zirconia, lithium di-silicate and nano-fluorapatite glass ceramic with two finishing procedures polishing and glazing, and their effect on the wear of natural tooth antagonists. Material and Methods: Forty two ceramic disc specimens $(10 \mathrm{~mm}$ $\mathrm{x} 3 \mathrm{~mm}$ ) and forty two natural tooth antagonists were used. Samples were divided according to ceramic materials into 3 groups $(\mathrm{n}=14)$. Group I: nano-fluorapatite glass ceramic (FLU) (IPS e.max Ceram), Group II: lithium disilicate (LD) (IPS e.max CAD) and group III: monolithic zirconia (ZIR) (ZirkoZahn Prettau). Each group was further subdivided into two subgroups ( $\mathrm{n}=7$ ), according to the surface finish: Polishing (P) and glazing (G). Specimens were subjected to a custom designed two-body wear simulator. Quantitative wear assessment was carried out using weight loss measurements. Scanning electron microscope was used for characterization of wear patterns. Kruscal Wallis and Dunn's tests were used to compare between weight loss of the three ceramic materials. Whitney $\mathrm{U}$ test was used to compare the weight loss between the two surface finish protocols. Wilcoxon Signed rank test was used to compare the weight loss between ceramic specimens and antagonist teeth ( $\mathrm{p} \leq$ 0.05). Paired t-test was used to compare weight loss before and after wear test. Results: After wear, LD and FLU had the highest weight loss values compared to ZIR ( $\mathrm{p}<0.05$ ). For teeth, there was no significant difference between the weight loss values with the three materials $(\mathrm{p}>0.05)$. $\mathrm{P}$ and $\mathrm{G}$ specimens showed no significant difference in weight loss values. SEM images of the wear patterns verified the previous analysis. Conclusion: ZIR is more wear resistant than LD and FLU. However, the surface treatment had no impact on the wear behavior.
\end{abstract}

\section{KEYWORDS}

Glass-ceramics; Monolithic; Two-body wear simulation; Wear; Zirconia.

\section{RESUMO}

Objetivo: Avaliar e comparar o comportamento ao desgaste de três diferentes sistemas cerâmicos; zircônia monolítica, di-silicato de lítio e vitrocerâmica de nano-fluorapatita com dois procedimentos de polimento e glaze, e seu efeito no desgaste de dentes naturais antagonistas. Material e Métodos: Foram utilizadas quarenta e duas amostras de discos cerâmicos (10 mm x $3 \mathrm{~mm})$ e quarenta e dois dentes naturais como antagonistas. As amostras foram divididas de acordo com o material cerâmico em 3 grupos ( $\mathrm{n}=$ 14). Grupo I: vitrocerâmica nano-fluorapatita (FLU) (IPS e.max Ceram), Grupo II: dissilicato de lítio (LD) (IPS e.max CAD) e grupo III: zircônia monolítica (ZIR) (ZirkoZahn Prettau). Cada grupo foi subdividido em dois subgrupos ( $\mathrm{n}=7$ ), de acordo com o acabamento da superfície: Polimento (P) e Glaze (G). As amostras foram submetidas a um simulador de desgaste de dois corpos projetado. A avaliação quantitativa do desgaste foi realizada usando medidas de perda de massa. Microscópio eletrônico de varredura foi utilizado para caracterização de padrões de desgaste. Os testes de Kruscal Wallis e Dunn foram usados para comparar a perda de massa dos três materiais cerâmicos. O teste U de Whitney foi utilizado para comparar a perda de massa entre os dois protocolos de acabamento superficial. O teste de Wilcoxon Signed Rank foi utilizado para comparar a perda de massa entre amostras de cerâmica e os dentes antagonistas $(\mathrm{p} \leq 0,05)$. O teste t pareado foi utilizado para comparar a perda de massa antes e depois do teste de desgaste. Resultados: Após o desgaste, LD e FLU apresentaram os maiores valores de perda de massa em comparação ao ZIR (p $<0,05)$. Para os dentes, não houve diferença significativa entre os valores de perda de massa com os três materiais ( $p>0,05$ ). As amostras de P e $G$ não mostraram diferença significativa nos valores de perda de massa. Imagens SEM dos padrões de desgaste confirmaram a análise anterior. Conclusão: O ZIR é mais resistente ao desgaste do que LD e FLU. No entanto, o tratamento de superfície não teve impacto no comportamento do desgaste.

\section{PALAVRAS-CHAVE}

Vitrocerâmica; Monolítica; Simulação de desgaste de dois corpos; Desgaste; Zircônia. 


\section{INTRODUCTION}

$\mathrm{T}$ he increased demand for esthetics in dentistry has led researchers to create ceramic restorations to mimic the appearance of natural teeth and eliminate the need for metal substructures [1]. Nano-fluorapatite glass is a new generation of dental layering ceramic which is ideal for finishing dental restorations. It contains apatite crystals which closely resemble those found in enamel, helping to achieve a natural appearance. It can be used as a veneering ceramic with glass ceramics as well as zirconium oxide [2]. Lithium disilicate is among the most widely used type of glass ceramics, it offers excellent strength and durability as well as outstanding optical properties [3]. Ever since the discovery of the unique transformation toughening capabilities and resistance to crack propagation of zirconia, it has become one of the main focuses for research. Its mechanical properties are basically the highest reported ever for dental ceramics, that is why its clinical use has increased [4,5].

The introduction of monolithic ceramics can provide exceptional esthetics without requiring a veneering ceramic. Greater structural integrity can be achieved by eliminating the veneered ceramic and the bond interface. Monolithic glass ceramics such as lithium disilicate offer exceptional esthetics. The 70\% crystal phase of this material improved flexural strength, while refracting light in a natural manner, therefore expanding the range of its indications [6-8]. Monolithic zirconia restorations, overcame many drawbacks of veneered zirconia based restorations $[1,4,9]$

The wear of teeth is irreversible and cumulative with age. The problems associated with wear are likely to place greater demands upon dental professionals [10]. Tooth wear affects the quality of life for patients. Therefore, there is a need for highly qualified dental restorative materials to repair or replace teeth [11]. With the continuous development in dental industry, wear resistance of newer esthetic restorative materials has generally improved, and the damage to the opposing dentition has been reduced, such materials include new low fusing ceramics, resin nano-ceramics, polymer infiltrated glass ceramics (hybrid ceramics) and novel monolithic self-glazed zirconia [11-14]. However, the different structures and physical properties of teeth and restorative materials will eventually lead to varying degrees of differential wear [15]. Therefore, the selection of restorative materials must be based on knowledge of their wear behavior and individual needs of each patient [16]. Several previous studies [4,17-19] provided us with useful data regarding the wear resistance properties and the effect of different ceramics on opposing antagonists.

Different scenarios of finishing procedures are available: grinding, polishing and glazing to create ceramic restorations with smooth surfaces. The effect of the surface finish on wear performance of the ceramic material and tooth antagonist has been widely published [20-23] with controversy in their results. This debate is dependent on the method chosen, procedure efficacy and material's microstructure [22-24].

Therefore, the aim of the present research was to evaluate and compare the wear behavior of three different ceramic systems; monolithic zirconia, lithium di-silicate and nano-fluorapatite glass ceramic with two finishing procedures polishing and glazing, and their effect on the wear of natural tooth antagonists. The first null hypothesis was that there would be no difference in the wear behavior of the three ceramic systems against natural teeth. The second null hypothesis was that different finishing procedures would have no influence on the wear behavior of the three ceramic systems against natural teeth.

\section{MATERIAL AND METHODS}

Materials used in this study are described in table I. Forty-two ceramic disc specimens were made with dimensions of $10 \mathrm{~mm}$ diameter x $3 \mathrm{~mm}$ height. The disc specimens were divided according to the ceramic materials into three equal groups $(n=14)$. Group I: FLU (Ivoclar Vivadent, Schann, Lichtenstein, Germany), group II: LD (Ivoclar Vivadent, Schann, Lichtenstein, Germany), and group III: ZIR (ZirkonZahn, Streger, Ahrntal, Italy). Each group was further subdivided into two equal subgroups according to the surface finish protocol; $P$ and $G(n=7)$.

A total of 42 caries-free human maxillary central incisors which were extracted due to periodontal disease were used for this research (IRB Number = 44912). After disinfection, the samples were stored in a saline solution. For fixation during two-body wear simulation, each tooth was individually mounted in epoxy resin blocks (KemaPoxy 150, CMB International. ARE). 
Table I - materials used in this study

\begin{tabular}{|c|c|c|c|c|}
\hline Ceramic materials & Construction technique & Manufacturer & Chemical composition in weight $\%$ & Lot\# \\
\hline FLU $^{*}$ & Conventional build-up technique & $\begin{array}{l}\text { Ivoclar, Vivadent, Schaan } \\
\text { Liechtenstein }\end{array}$ & $\begin{array}{c}\cdot \mathrm{SiO}_{2}[60.0-65.0] \\
\cdot \mathrm{Al}_{2} \mathrm{O}_{3}[8.0-12.0] \\
\cdot \mathrm{Na}_{2} \mathrm{O}[6.0-9.0] \\
\cdot \mathrm{K}_{2} \mathrm{O}[6.0-8.0] \\
\cdot \mathrm{ZnO}^{2}[2.0-3.0] \\
\cdot+\mathrm{CaO}, \mathrm{P}_{2} \mathrm{~F}_{5}[2.0-6.0] \\
\text { +other oxides }[2.0-8.5] \\
\cdot \text { + pigments }[0.1-1.5]\end{array}$ & R81614 \\
\hline $\mathbf{L D}^{\star \star}$ & CAD/CAM & $\begin{array}{l}\text { Ivoclar, Vivadent, Schaan Liech- } \\
\text { tenstein }\end{array}$ & $\begin{aligned} & \cdot \mathrm{SiO}_{2}[57.0-80.0] \\
& \cdot \mathrm{LiO}_{2}[11.0-19.0] \\
& \cdot \mathrm{K}_{2}[0.0-13.0] \\
& \cdot \mathrm{P}^{2} \mathrm{O}_{5}[0.0-11.0] \\
& \cdot \mathrm{Zr}_{2}[0.0-8.0] \\
& \cdot \mathrm{ZnO} 0[0.0-8.0] \\
& \text {. Other and coloring oxides }[0.0-12.0]\end{aligned}$ & R80027 \\
\hline $\mathbf{Z} \mathbf{R}^{\star \star \star}$ & CAD/CAM & Zirkonzahn, Steger, Ahrntal, Italy. & $\begin{array}{l}\cdot \mathrm{ZrO}_{2}\left(+\mathrm{HfO}_{2}\right) \\
\cdot\left[\mathrm{Main} \mathrm{component}_{0}\right] \\
\cdot \mathrm{Y}_{2} \mathrm{O}_{3}[4.95-5.26] \\
\cdot \mathrm{Al}_{2} \mathrm{O}_{3}[0.15-0.35] \\
\cdot \mathrm{Si}_{2}[\mathrm{Max} .0 .02] \\
\cdot \mathrm{Fe}_{2} \mathrm{O}_{3}[\mathrm{Max} .0 .01] \\
\cdot \mathrm{Na}_{2} \mathrm{O}_{3}[\mathrm{Max} .0 .04]\end{array}$ & ZRAD8021 \\
\hline Antagonists & \multicolumn{4}{|c|}{ Natural maxillary central incisors } \\
\hline
\end{tabular}

${ }^{*}$ IPS e.max® Ceram. Scientific documentation. Ivoclar Vivadent AG. www.ivoclarvivadent.com ${ }^{* \star}$ IPS e.max® CAD. Scientific documentation. Ivoclar Vivadent AG. www.ivoclarvivadent.com

***ZirkonZahn, human zirconium technology. Zirconia-information for dentists. FAQ's-from the dental practice. ZirkonZahn worldwideAn der Ahr 7-39090 Gais/South Tirol (Italy). www.Zirkonzahn.com

\section{Construction of IPS e.max Ceram disc} specimens

In order to standardize the shape and the dimensions of FLU using conventional build up technique, a specially designed mold was constructed. An outer metal ring was designed to support an inner Teflon mold with the desired dimension of $10 \mathrm{~mm}$ diameter and $3 \mathrm{~mm}$ height. The Teflon mold was split to allow easy removal of the discs after the build-up process [25]. The powder (Ivoclar Vivadent, Shaan, Liechtenstein, Germany) was mixed with the build-up liquid (Ivoclar Vivadent, Shaan, Liechtenstein, Germany) according to the manufacturer's instructions. The slurry mix was packed and condensed into the mold and blotted with a dry tissue to remove excess liquid. Ceramic disc specimens were fired in the ceramic furnace, Ivoclar Vivadent Programat EP 3010 (Ivoclar Vivadent, Shaan, Liechtenstein, Germany) following the manufacturer's instructions (table II). For G subgroup specimens, IPS e.max Ceram glaze powder (Ivoclar Vivadent, Shaan, Liechtenstein, Germany) was mixed with e.max Ceram glaze and stain liquid (Ivoclar Vivadent, Shaan, Liechtenstein, Germany), applied on the disc surfaces and fired according to the manufacturer's instructions (table II) . For P subgroup specimens, polishing was done using the SHOFU porcelain adjustment kit (SHOFU INC. 11 Kamitakamatsu, Fukuine, Higashiyama-ku, Kyoto 605-0983 Japan) following the manufacturer's instructions. The kit has three Dura-White Stones for adjusting, three Ceramiste Standard Polishers for prepolishing, and three Ultra (yellow-band) Polishers for polishing and three Ultra II (whiteband) Polishers for super- polishing. Polishing of the samples was done in a sequential order followed by a diamond polishing paste (ADS, American Dental Supply, INC, USA) for a smooth finish. 
Table II - Firing parameters of FLU (Transpa Incisal) and LD (LT) with or without the application of IPS e.max CAD Crystal/ Glaze paste

\begin{tabular}{|cccc|}
\hline Firing parameters & FLU & Glaze firing of FLU & LD \\
\hline Closing time $\mathrm{Smin}$. & 8 & 8 & $6: 00$ \\
\hline Stand-by temperature $\mathrm{B}\left[{ }^{\circ} \mathrm{C}\right]$ & 403 & 403 & 403 \\
\hline $\begin{array}{c}\text { Heating rate } \\
\mathrm{t} \rightarrow[0 \mathrm{C} / \mathrm{min}]\end{array}$ & 50 & 50 & - \\
\hline Heating rate $\left.\mathrm{t} 1{ }^{\circ} \mathrm{C} / \mathrm{min}\right]$ & - & - & 90 \\
\hline Firing temperature $\mathrm{T1}\left[{ }^{\circ} \mathrm{C}\right]$ & 770 & 740 & 820 \\
\hline Holding time $\mathrm{H}[\mathrm{min}]$ & 1 & 1 & - \\
\hline Holding time $\mathrm{H} 1[\mathrm{~min}]$ & - & - & $0: 10$ \\
\hline Heating rate $2\left[{ }^{\circ} \mathrm{C} / \mathrm{min}\right]$ & - & - & 30 \\
\hline Firing temperature $\left.\mathrm{T} 2{ }^{\circ} \mathrm{C}\right]$ & - & - & 840 \\
\hline Holding time $\mathrm{H} 2[\mathrm{~min}]$ & - & - & $7: 00$ \\
\hline Long-term cooling $\mathrm{L}\left[{ }^{\circ} \mathrm{C}\right]$ & 0 & 0 & 700 \\
\hline Cooling rate $\mathrm{t}\left[{ }^{\circ} \mathrm{C} / \mathrm{min}\right]$ & 0 & 0 & 0 \\
\hline Vacuum $11112\left[{ }^{\circ} \mathrm{C}\right]$ & 450 & 450 & 550 \\
\hline Vacuum $22122\left[{ }^{\circ} \mathrm{C}\right]$ & 769 & 739 & 820 \\
\hline & & & 840 \\
\hline
\end{tabular}

\section{Construction of zirconia disc specimens}

For construction of ZIR samples, the previously mentioned metal disc with the same dimensions [26], was scanned by fully automated optical scanner S60 (ZirkonZahn, Steger, Ahrntal, Italy). Virtual disc was designed by using a special software (ZirkonZahn Modellier) (ZirkonZahn, Steger, Ahrntal, Italy). Zirconia discs were milled by using 5-axes milling unit M5 (ZirkonZahn, Steger, Ahrntal, Italy). Coloring and sintering of zirconia discs were carried out in the sintering furnace, Zirkonofen 600 (ZirkonZahn, Steger, Ahrntal, Italy) following the manufacture's recommendations (table III). For G subgroup specimens, Glaze Plus (ZirkonZahn, Steger, Ahrntal, Italy) was applied over the disc surfaces and fired following the manufacturer's recommendations (table III). While for $\mathrm{P}$ subgroup, polishing was done manually with lab hand-piece using silicon polishers according to the manufacturers' instructions.
Table III - Firing parameters of ZIR

\begin{tabular}{|cc|}
\hline Start temperature & $300^{\circ} \mathrm{C}$ \\
\hline Drying time & $2 \mathrm{~min}$ \\
\hline Heating time & $6 \mathrm{~min}$ \\
\hline Heat rise & $25-55^{\circ} \mathrm{C} / \mathrm{min}$ \\
\hline Biscuit (1st) fire & $820^{\circ} \mathrm{C}\left(+/-10^{\circ} \mathrm{C}\right)$ \\
\hline Stain/coloring liquid fire & $730^{\circ} \mathrm{C}, 1 \mathrm{~min}$ holding time \\
\hline Glaze fire & $780-800^{\circ} \mathrm{C}, 1$ min holding time \\
\hline Holding time & $2-3$ min \\
\hline Firing temperature & $16000 \mathrm{C}$ \\
\hline Vacuum on & $400-500^{\circ} \mathrm{C}$ \\
\hline Vacuum off & $820^{\circ} \mathrm{C}\left(+/-10^{\circ} \mathrm{C}\right)$ \\
\hline Vacuumlevel & max \\
\hline Cooling & $3-10 \mathrm{~min}$, depending on mass \\
\hline
\end{tabular}

\section{Thermo-cycling}

All ceramic disc specimens were subjected to thermo-cycling before wear testing (Julabo, Germany) in distilled water for 3500 cycles at changing temperatures between $5^{\circ} \mathrm{C}$ and $55^{\circ} \mathrm{C}$, with the duration of 2 minutes for each cycle [27]. Thermo-cycling was done to simulate intra-oral conditions.

\section{Wear testing}

A specially constructed two-body wear simulator was particularly designed to perform this research (figures 1,2). The custom designed two-body wear simulator simulates horizontal movements that occur naturally in oral cavity. The machine was deployed inside a $250 \mathrm{~mm} \times 400 \mathrm{~mm}$ $\mathrm{x} 600 \mathrm{~mm}$ steel metal frame casing (figure 1b) which carries the whole mechanism. The machine was composed of upper (figure 2f) and lower (figure $2 \mathrm{~g}$ ) sample holders. Both sample holders were designed to be emerged inside a plastic beaker (figure $2 \mathrm{~b}$ ) that is filled with distilled water in which the process will occur. The upper sample holder is attached by two M4 socket head screws on the power screw nut; which is a main component of the driver head, it was connected rigidly to guarantee no vibration between the ceramic sample and antagonist tooth during the operation. The power screw and, in turn, the nut are actuated by a pneumatic piston in a rocker mechanism, connected to it by a low vibration coupling wheel; 
which transmits the motion from the mechanism to the antagonist causing friction over the sample. The lower sample holder was designed to hold ceramic samples, while the upper sample holder was designed to be home for an antagonist natural tooth in a positive mold. The pneumatic circuit is actuated via a $2 \mathrm{HP}$ air compressor with a $25 \mathrm{~L}$ tank that gives the required power supply. The simulator was programmed to perform 2.4 x 106 loading cycle backwards and forwards (figure 3) by holding an antagonist (figure 3a) against a sample (figure $3 \mathrm{~b}$ ) which are comparable to one year chewing condition [4].
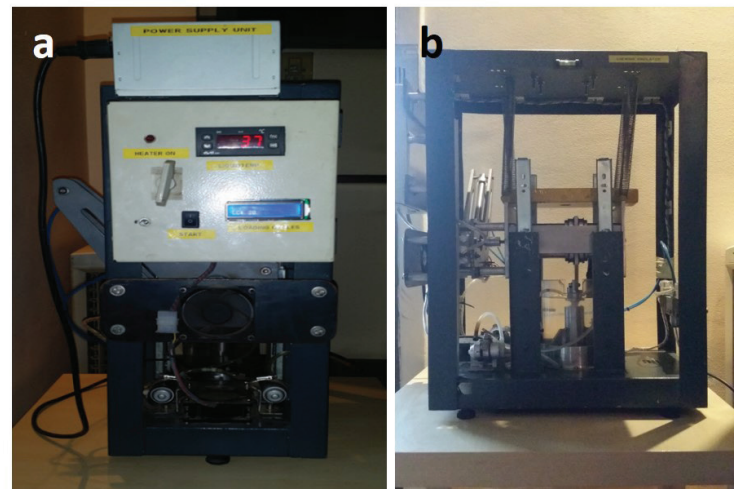

Figure 1 - Two-body wear simulator: a, side view showing the driver head of the machine, power supply unit, temperature control unit and monitor. $b$, shows the machine which is deployed inside a steel metal frame.

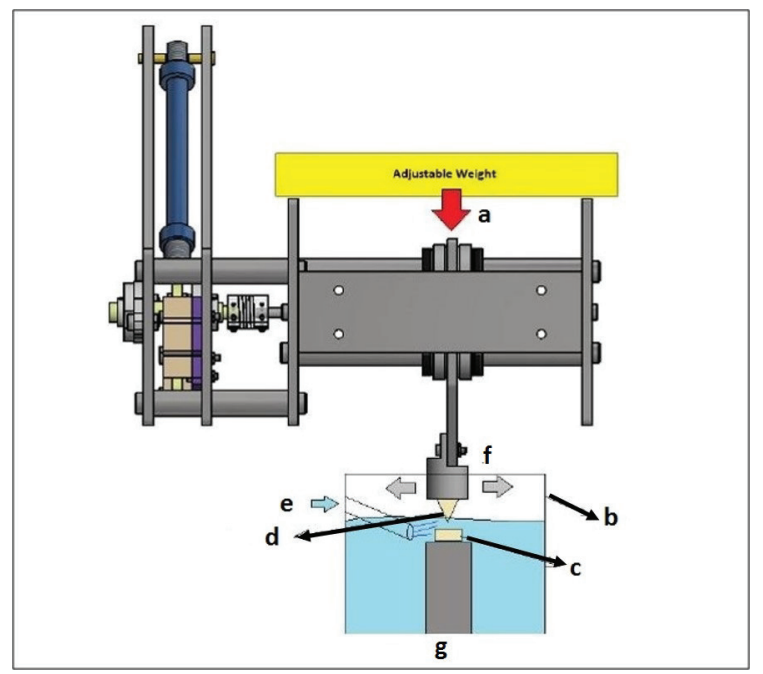

Figure 2 - Schematic Diagram representing the two-body wear process orientation; a, weight. b, plastic beaker. c, ceramic sample. d, natural teeth antagonist. e, water jet (2 seconds on/30 seconds off). f, upper sample holder. g, lower sample holder.

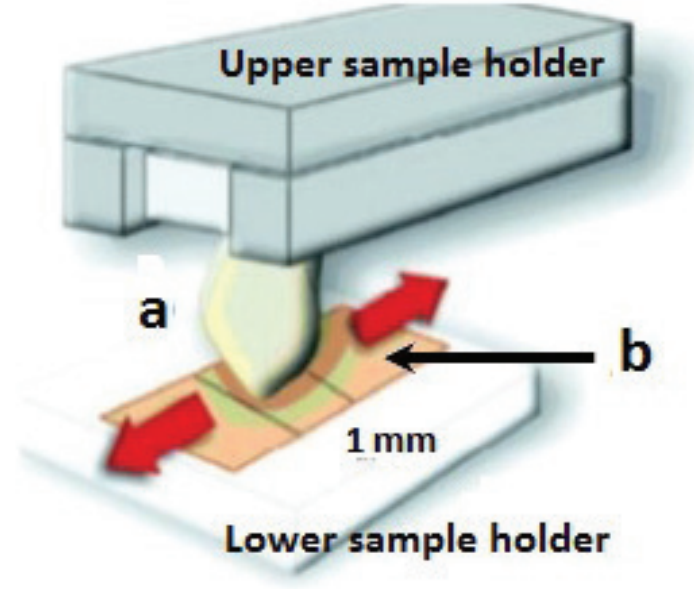

Figure 3 - Diagram representing the stroke direction and length during two-body wear simulation process; the natural tooth antagonist (a) moved horizontally backwards and forwards (red arrows) and $1 \mathrm{~mm} /$ direction over the ceramic sample (b).

Wear parameters, stroke length/ horizontal movement, frequency of loading cycles, operational liquid temperature, water jet frequency and weight per sample could be adjusted according to different experimental conditions. The applied load can be changed by simply changing the weights (figure 2a) that are inserted over the machine driver. The loading cycles can be increased or decreased by reprogramming the system's controller and so is the stroke length. The temperature is adjustable from the temperature unit on the control panel (figure 1a) and is always monitored by a thermosensor mounted on the operation beaker. Water jet (figure 2e) cleaning frequency can also be adjusted from knobs inside the control unit.

For fixation during two-body wear simulation, the specimens were embedded in the middle of their holders using a light cured dental composite resin (Hybrid light cure composite. Alpha-dent, 6901 N Hamlin Avenue, Lincolnwood, Illinois 60712 , USA) to ensure proper positioning during the test. A weight of $5 \mathrm{~kg}$, which is equivalent to $49 \mathrm{~N}$ of chewing force $[23,24]$ was applied over the machine driver. A number of $2.4 \times 106$ cycles were repeated on each sample at a frequency of $1.7 \mathrm{~Hz}$ (which equals to 102 cycles/minute). The stroke length of the horizontal movement equals to $1 \mathrm{~mm}^{2}$ (figure 3 ). A continuous flow of distilled water was directed on the wear area maintaining the environmental temperature at $37^{\circ} \mathrm{C}$. 


\section{Weight loss measurement}

Ceramic samples and teeth were separated and sequentially numbered so that the same sample had its weight measured before and after wear testing. Samples were weighed in an electronic balance (Sartorius, Biopharmaceutical and Laboratories, Germany) with an accuracy of 0.0001 gr [28].

\section{Scanning electron microscope (SEM)}

For characterizing wear patterns, one representative ceramic sample and one tooth from each subgroup (before and after two-body wear test) was selected for SEM using the FEI Quanta 250 FEG-SEM (FEI COMPANY, Nederland) attached with EDAX Unit (Energy Dispersive X-ray Analyses), with accelerating voltage $30 \mathrm{kV}$. Natural teeth were examined at a magnification of $160 x$, while ceramic samples were examined at a magnification of 1000x.

\section{Statistical Analysis}

Numerical data were explored for normality by checking the distribution of data and using tests of normality (Kolmogorov-Smirnov and Shapiro-Wilk tests). Weight loss data showed nonparametric (non-normal) distribution according to tests of distribution. Data were presented as mean, median, standard deviation (SD), minimum, maximum and $95 \%$ Confidence Interval (95 $\% \mathrm{CI}$ ) for the mean values. Kruskal-Wallis test was used to compare between weight loss of the three ceramic materials. Dunn's test was used for pair-wise comparisons when Kruskal- Wallis test is significant. Mann-Whitney U test was used to compare between the two surface finishes ( $G$ and $\mathrm{P})$. Wilcoxon signed-rank test was used to compare between specimens and antagonist teeth. Paired t-test was used to compare weight loss before and after wear test. The significance level was set at $\mathrm{p} \leq 0.05$. Statistical analysis was performed with IBM ${ }^{\circledR}$ SPSS ${ }^{\circledR}$ statistics Version 20 for Windows.

\section{RESULTS}

\section{Weight loss}

For $\mathrm{P}$ as well as $\mathrm{G}$ ceramic specimens, there was no significant difference between LD and FLU. Both showed significantly the highest mean weight loss values; while ZIR showed significantly the lowest mean weight loss values $\mathrm{p} \leq 0.05$. As for their tooth antagonist, no significant difference was found in the mean weight loss values among the three ceramic materials (table IV). For all groups, whether for the ceramic specimens or teeth antagonists, there was no statistically significant difference in the mean weight loss values between $P$ and $G$ specimens (figure 4). Ceramic specimens had statistically significantly lower mean weight loss values than teeth antagonists' $\mathrm{p} \leq 0.05$ (figure 5). There was a significant decrease in weight after wear procedure for all the ceramic specimens except for G-FLU specimens and P-FLU teeth antagonists as there was a decrease in weight but not statistically significant (table IV).

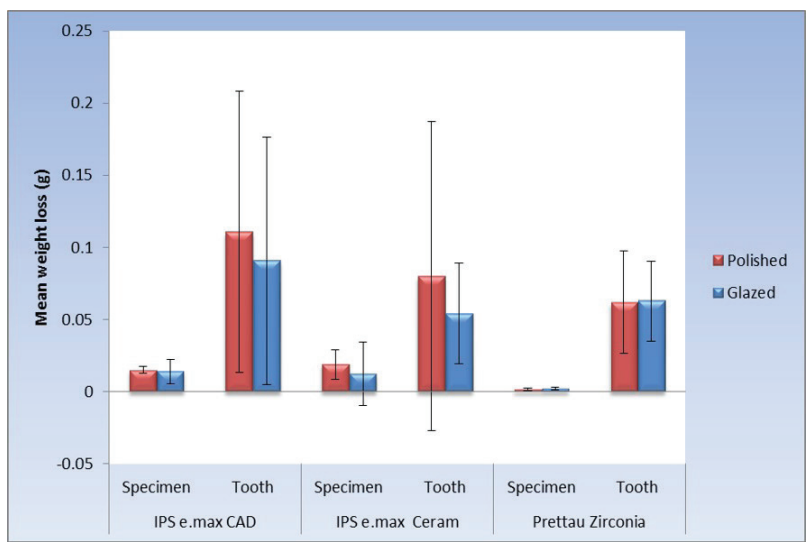

Figure 4 - Bar chart representing mean and standard deviation values of weight loss of polished and glazed ceramic specimens with different interactions.

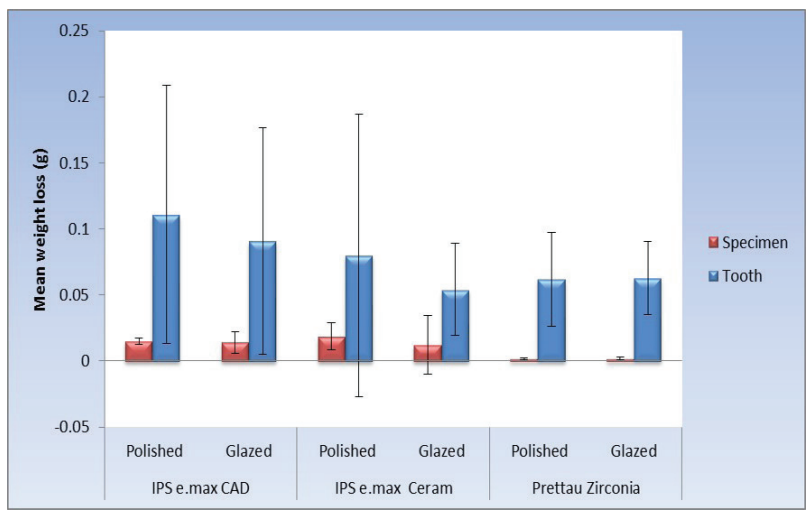

Figure 5 - Bar chart representing mean and standard deviation values of weight loss of ceramic specimens and tooth antagonists. 
Table IV - The mean, standard deviation (SD) values and results of paired t-test for comparison between weights before and after wear within each group

\begin{tabular}{|c|c|c|c|c|c|c|c|}
\hline \multirow{2}{*}{ Substrate } & \multirow{2}{*}{ Material } & \multirow{2}{*}{$\begin{array}{c}\text { Surface } \\
\text { finish }\end{array}$} & \multicolumn{2}{|c|}{ Before wear } & \multicolumn{2}{|c|}{ After wear } & \multirow{2}{*}{$P$-value } \\
\hline & & & Mean & SD & Mean & SD & \\
\hline \multirow{6}{*}{ Specimen } & \multirow{2}{*}{$\begin{array}{c}\text { IPSe.max } \\
\text { CAD }\end{array}$} & Polished & 0.6429 & 0.0057 & 0.6280 & 0.0072 & $<0.001^{*}$ \\
\hline & & Glazed & 0.6471 & 0.0104 & 0.6330 & 0.0103 & $0.004^{*}$ \\
\hline & \multirow{2}{*}{$\begin{array}{l}\text { IPS e.max } \\
\text { Ceram }\end{array}$} & Polished & 0.9315 & 0.0254 & 0.9128 & 0.0242 & $0.003^{\star}$ \\
\hline & & Glazed & 0.8907 & 0.0313 & 0.8784 & 0.0231 & 0.192 \\
\hline & \multirow{2}{*}{$\begin{array}{l}\text { Prettau } \\
\text { Zirconia }\end{array}$} & Polished & 1.8499 & 0.0370 & 1.8482 & 0.0371 & $0.003^{\star}$ \\
\hline & & Glazed & 1.962 & 0.1135 & 1.9595 & 0.1140 & $0.001^{*}$ \\
\hline \multirow{6}{*}{ Tooth } & \multirow{2}{*}{$\begin{array}{l}\text { IPS e.max } \\
\text { CAD }\end{array}$} & Polished & 2.339 & 0.1276 & 2.2279 & 0.1674 & $0.024^{*}$ \\
\hline & & Glazed & 2.2824 & 0.1833 & 2.1917 & 0.1448 & $0.031^{*}$ \\
\hline & \multirow{2}{*}{$\begin{array}{l}\text { IPS e.max } \\
\text { Ceram }\end{array}$} & Polished & 2.3110 & 0.1625 & 2.2310 & 0.1413 & 0.095 \\
\hline & & Glazed & 2.2923 & 0.1125 & 2.2383 & 0.1219 & $0.006^{*}$ \\
\hline & \multirow{2}{*}{$\begin{array}{l}\text { Prettau } \\
\text { Zirconia }\end{array}$} & Polished & 2.3550 & 0.1371 & 2.2931 & 0.1461 & $0.004^{*}$ \\
\hline & & Glazed & 2.3314 & 0.0894 & 2.2686 & 0.0980 & $0.001^{\star}$ \\
\hline
\end{tabular}

*: Significant at $P \leq 0.05$

\section{Scanning Electron microscope analysis}

SEM analysis of P and G LD, FLU and ZIR ceramic surfaces and tooth antagonists are presented in (figures $6,7,8,9,10,11$ ). Before two-body wear test, SEM photomicrographs of all polished ceramic surfaces show striations which indicate the direction of polishing (figures 6a, 8a, 10a) while glazed surfaces show uniform glaze layer underneath crystalline structure (figures 7a, 9a, 11a). After two-body wear test, SEM photo-micrographs of worn surfaces of all tested ceramics whether polished or glazed reveal that the wear pattern was more evident in LD and FLU (figures 6c, 7c, 8c, 9c) than ZIR (figures 10c, 11c) which is mildly affected. Regarding the natural teeth, SEM photo-micrographs reveal that the wear pattern of worn enamel opposed to polished or glazed ZIR surfaces (figures 10d,11d) appear as very faint striations parallel to one another which are not deep as worn enamel opposed to $P$ or G LD and FLU surfaces (figures $6 \mathrm{~d}, 7 \mathrm{~d}$, 8d, 9d).
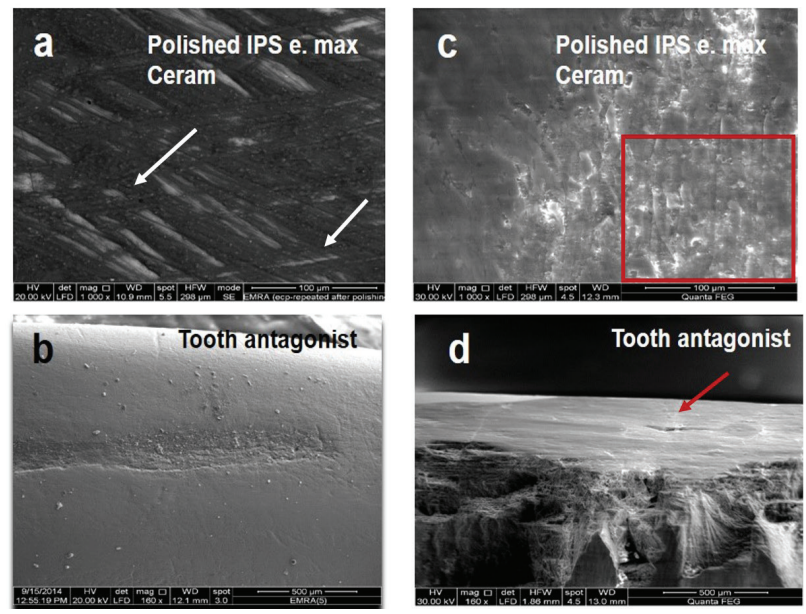

Figure 6 - SEM images of FLU-P (Magnification 1000x) and tooth antagonist (Magnification 160x); a and b; before two-body wear test. c and d; After two-body wear test. a; FLU-P surface shows pulling out of some grains/crystals resulted from polishing. c; The microstructure of the worn ceramic surface started to prevail. b; smooth incisal edge. d; parallel striations of the wear pattern (hardly detected). White arrows represent the direction of polishing process. Red arrow represents crack propagation directed sideways. Red square represents furrows which are neither faint nor deep (in between).
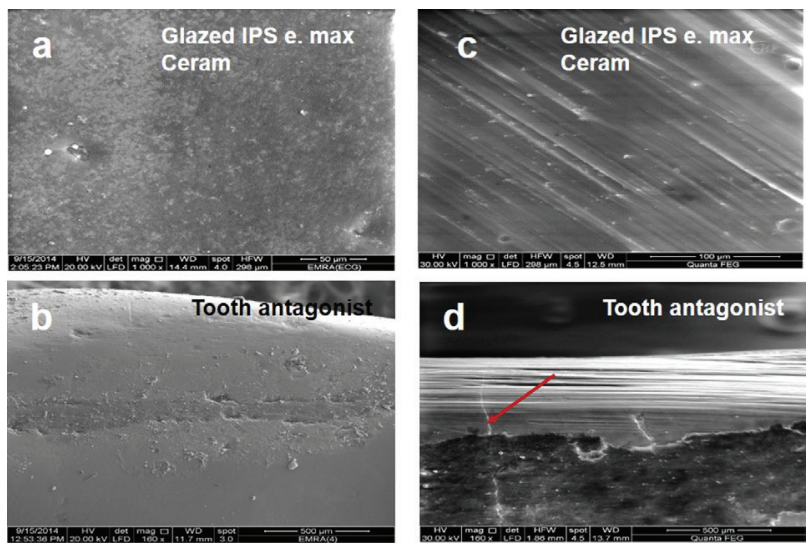

Figure 7 - SEM images of FLU-G (Magnification 1000x) and tooth antagonist (Magnification 160x); a and b; before two-body wear test. c and d; After two-body wear test. a; the FLU-G shows a transparent glaze layer, underneath it a uniform crystalline structure. b; a smooth incisal edge. c; The worn FLU-G surface shows pulling out of some crystals across the parallel striations of the wear pattern. The glazed surface remained intact but is clearly affected. d; worn incisal edge. The wear pattern in the form of long, parallel, deep striations forming a uniform broad surface. Red arrow represents site of crack propagation which moves upwards. 


Wear behavior of monolithic zirconia against natural teeth in comparison to
two glass ceramics with two surface finishing protocols: an in-vitro study
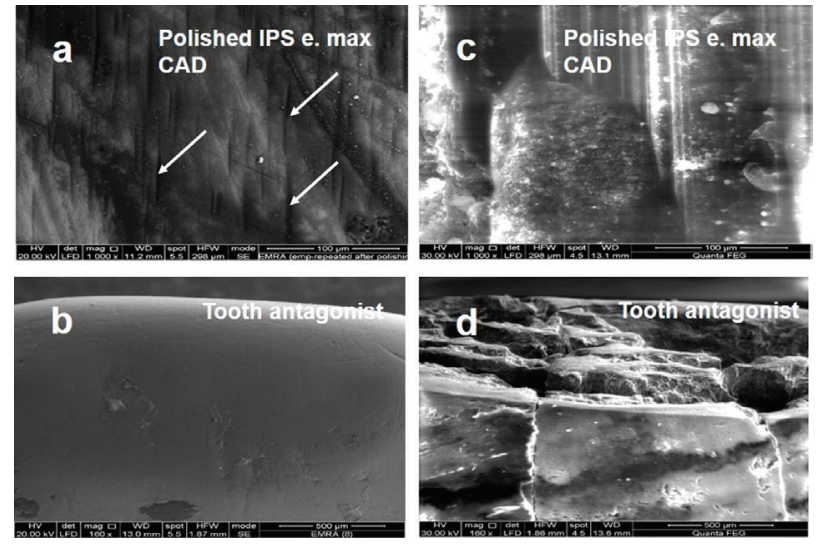

Figure 8 - SEM images of LD-P (Magnification 1000x) and tooth antagonist (Magnification 160x); a and b; before two-body wear test. $c$ and d; After two-body wear test. a; the surface shows striations and pulling out some of the grains/crystals. b; smooth incisal edge. c; The worn surface shows very deep furrows and subsidiary grooves which are parallel to one another and to the main furrow. $d$; the worn incisal edge detected as very deep furrows and islands of crystals. White arrows represent the direction of polishing process.
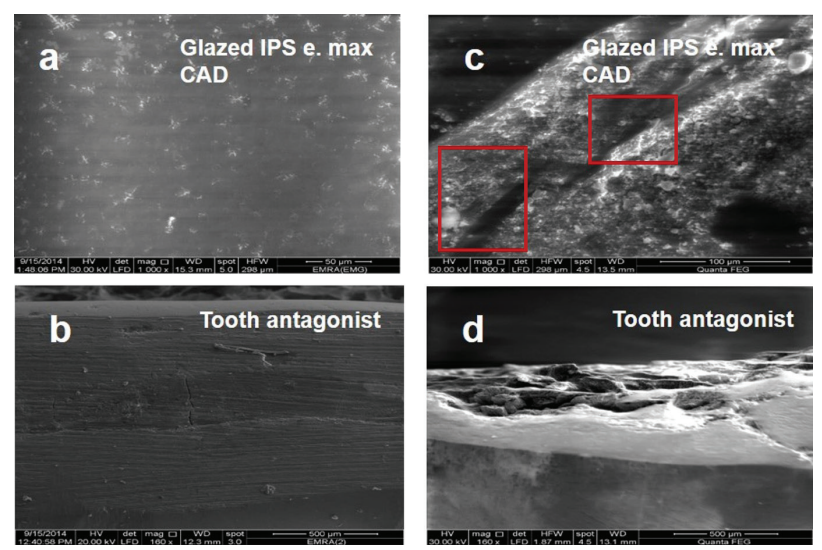

Figure 9 - SEM images of LD-G (Magnification 1000x) and tooth antagonist (Magnification 160x); $a$ and b; before two-body wear test. c and d; After two-body wear test. a; the surface shows a uniform glaze and dendritic shaped crystals appearing under it. b; a smooth incisal edge. c; The worn surface shows a uniform crystalline microstructure. Relics of the glazed surface remain scattered and are seen lighter in color. d; the worn incisal edge shows pulling out of the enamel crystals which somehow preserved their shape. red squares represent deep furrows.
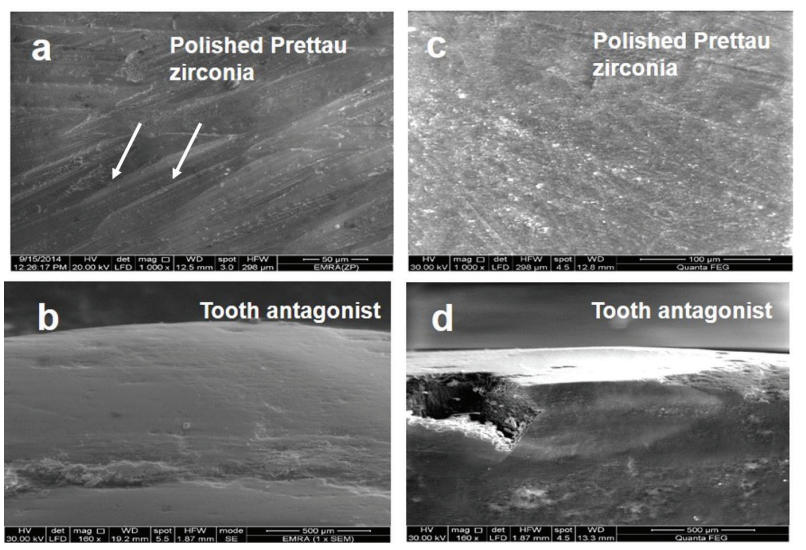

Figure 10 - SEM images of ZIR-P (Magnification 1000x) and tooth antagonist (Magnification 160x); $a$ and b; before two-body wear test. $\mathrm{C}$ and d; After two-body wear test. a; the surface shows striations b; smooth incisal edge. c; The worn surface shows shallow parallel striations. d; The worn incisal edge appears as very faint striations parallel to one another where the contact point is the only affected.
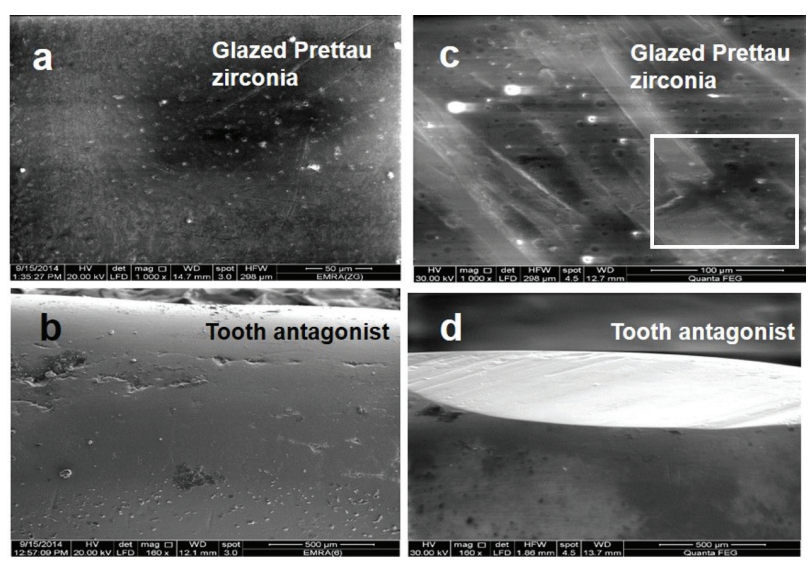

Figure 11 - SEM images of ZIR-G (Magnification 1000x) and tooth antagonist (Magnification 160x); a and b; before two-body wear test. $\mathrm{c}$ and d; After two-body wear test. a; the surface shows a uniform layer of glaze and small dendritic crystals. b; smooth incisal edge. c; the worn surface shows short spindleshaped lines, parallel to one another (they have a starting and ending point). The glazed surface appears to remain intact. d; The worn incisal edge appears as very faint striations parallel to one another where the contact point is the only affected. white square represents short spindle-shaped line. 


\section{DISCUSSION}

The results of this study showed that the wear behavior is material-dependent and different finishing procedures ( $P$ and $G$ ) have no influence on the wear behavior of the three ceramic systems against natural teeth. So, the first null hypothesis was rejected and the second one was accepted.

In this study a specially designed two-body wear simulator was designed. In vitro testing has the advantages of a controlled exposure time, a high level of standardization, larger number of samples can be tested over a short time and it provides control over the testing environment and temperature $[15,29]$. The designed twobody wear simulator is programmed to perform $2.4 \times 10^{6}$ loading cycles backwards and forwards by holding the natural tooth antagonist against the ceramic disc sample. According to studies [4,23], $2.4 \times 10^{6}-2.5 \times 10^{6}$ loading cycles in a chewing simulator are comparable to a one-year chewing condition. The stroke length/ horizontal movement of the antagonist natural tooth over the ceramic sample equals to $1 \mathrm{~mm}^{2}$ per direction [17]. The frequency of the loading cycles was set to be $1.7 \mathrm{~Hz}$ which equals 102 cycles/minute $[23,30]$. The samples were immersed in distilled water and a continuous flow was directed on the wear area maintaining the environmental temperature at $37^{\circ} \mathrm{C}$ [31]. A weight of $5 \mathrm{~kg}$, which is equivalent to $49 \mathrm{~N}$ of chewing force, was applied [23,24,32].

In the present study, difference in the composition of the tested ceramic materials was behind the significant higher weight loss of LD and FLU than ZIR. Both LD and FLU are glass ceramics. Fully sintered LD consists of approximately $70 \%$ fine-grain lithium di-silicate crystals embedded in a glassy matrix [33]. FLU consists of 19-23\% nano-fluorapatite crystals embedded in a glassy matrix [34], while ZIR is a polycrystalline ceramic, which consists of a fine uniform microstructure of 95\% zirconium oxide as a main component along with 4.95-5.26\% Yttrium oxide [35].

The low mean weight loss value of ZIR could be due to the inclusion of Yttria additives, which may have enabled the crystal structure to retard crack propagation and consequently lead to loss of slight amount of material from the surface [36]. The highest mean weight loss values of glass ceramics could be due to the disappearance of the weaker glass phase due to wear [36]. These findings came in agreement with those reported by several authors [32,38-40] who found that wear amount of lithium di-silicate was greater than that of zirconia. Albasharieh et al [36] found that zirconia specimens demonstrated significantly lower vertical and volumetric loss than nano-fluorapaptite and lithium di-silicate glass ceramics. SEM analysis verified out results as the wear patterns of both FLU and LD whether $P$ (figures $6 c$ and $8 c$ ) or $G$ (figures $7 c$ and 9c) were more evident than ZIR whether $P$ (figure 10c) or $\mathrm{G}$ (figure 11c).

In the current study, the non-significant difference in the weight loss between P and G ceramic specimens and teeth antagonists could be attributed to the fact that polishing and glazing are common methods used to create a smooth surface on ceramic restorations [24]. Glazing produces a final smooth hygienic surface and increases the overall mechanical strength of ceramic restorations by reducing porosity, reducing the depth and sharpness of surface flaws and blunting flaw tips [24]. Polishing, on the other hand, causes a reduction in initial surface flaws and defects inhibiting further crack propagation and, thus, increasing the restoration's resistance to fracture [41]. Also, polishing might produce residual compressive strength, consequently increasing ceramic surface hardness [41].

These results came in agreement with Magne et al. [31]. They found that wear characteristics of polished specimens were similar to that of glazed specimens when comparing wear of enamel against low fusing ceramics. They claimed that polishing can improve the surface roughness of the ceramic, similar to that of glazing [31]. Pries et al [32] compared wear of steatite antagonist against polished, glazed and adjusted lithium disilicate and zirconia and found no statistical significant difference between the three surface 
finishes. The reason behind such results could be that as the wear process continues, removal of the glaze layer or the glass matrix and exposure of crystalline phases may superimpose the original surface features, therefore an equal wear performance of both $\mathrm{P}$ and $\mathrm{G}$ surfaces might have occurred [32]. The results of the present study could also be attributed to the use of the Shofu polishing kit along with a diamond polishing paste for finishing LD and FLU and the silicon polishers for ZIR which can produce a smooth surface finish comparable to that of a glazed surface as claimed by several studies [42-45].The results of the present study partially agreed with those of Lawson et al [39], they found that glazed and polished lithium disilicate caused similar enamel wear, while polished zirconia caused less enamel wear than glazed zirconia. They explained that the glaze layer is softer and weaker and fractures during abrasion compared to the wear resistant surface of polished zirconia [39].

Other studies [4,23,30,46,47] came in disagreement with the findings of the present study, as they found more antagonist wear against glazed zirconia than polished zirconia. Perhaps this was due to the different methodology regarding applied force, number and frequency of loading cycles, number of specimens, as well as, different simulators used with diverse settings in their studies. Jung et al. [4] found that more wear was found in teeth opposing dental porcelain and claimed that the addition of porcelain composite during the glaze process of zirconia is the reason behind their results. On the contrary, Alves et al [48], found that the glaze surface finish of zirconia caused less wear on antagonists that the polished ones. Their explanation was that due to the thinness and homogeneity of the glaze layer, it abraded quickly forming no debris due to fracture and caused less abrasiveness to the antagonist [48]. Another contradicting study was that of Passos et al. [30], who found that more material wear was found in polished ceramic samples than glazed ones, they claimed that the glaze layer formed a protection to the ceramic surface and exhibited fewer cracks.
The lower weight loss values of the tested ceramic materials in this study, whether P or G than those of natural teeth could be attributed to the higher physical properties of the ceramics materials [33-35, 39, 47, 49, 50]. The results came in agreement with several studies [4, 22$24,30-32,36,39,51-53]$, who stated that most ceramics are more wear resistant than natural teeth. In the present study, difference in the wear patterns also became obvious in SEM evaluation which are more evident in the natural tooth antagonists (figures 6d, 7d, 8d, 9d, 10d, 11d) than those of the ceramic samples (figures $6 c, 7 c$, 8c, 9c, 10c, 11c).

In this study, decrease in the weight after two-body wear test in all ceramic materials, is likely to be attributable to the fact that wear process occurs whenever two surfaces interact with one another, causing loss of substance from the surfaces of materials. These results were in consistence with Albashaireh et al [36] and Mundhe et al [12]. They clarified that when ceramics slide against enamel, wear occurs by micro-fracture. They further explained that glass ceramics wear is mostly of fatigue type, which is initiated by the formation of cracks in the subsurface. Whereas zirconia commonly demonstrates a mode of wear consistent with adhesive or attritional wear, which happens when two surfaces slide against one another causing friction between them. SEM analysis revealed that several sites of crack propagation were seen on the natural teeth antagonists (figures $6 \mathrm{~d}, 7 \mathrm{~d}$ ) placed against FLU G and P samples. Also, LD-P sample demonstrated some dark lines which might indicate beginning of a fracture sight (fig 8c).

The limitations of the study, just like those of any in-vitro study, are that it remains unclear to what extent the wear observed clinically may differ. Only two-body wear test of ceramic specimens against natural teeth was evaluated. Further investigation should be required with a three-body wear test as different results may be obtained. Also, the number of specimens could have been increased to reduce influence of data variations on the statistical outcome. 


\section{CONCLUSIONS}

Despite the limitations of the present study, the following conclusions were drawn:

1 . Wear process of ceramics is materialdependent;

2. ZIR is more wear-resistant than $\mathrm{LD}$ and FLU glass ceramics;

3. The different tested ceramic materials and their surface finishing methods ( $G$ and $P$ ) did not influence the wear behavior of antagonist teeth.

\section{REFERENCES}

1. Kelly JR. Ceramics in restorative and prosthetic dentistry. Annu Rev Mater Sci. 1997 Aug;27(1):443-68. doi:10.1146/annurev.matsci.271.443.

2. IPS e.max®Ceram. Instructions for use. Ivoclar Vivadent AG. www. ivoclarvivadent.com

3. Tysowsky GW. The science behind lithium disilicate: a metal-free alternative. Dent Today. 2009 Mar;28(3):112-3.

4. Jung YS, Lee JW, Choi YJ, Ahn JS, Shin SW, Huh JB. A Study on the in-vitro wear of the natural tooth structure by opposing zirconia or dental porcelain. $\mathrm{J}$ Adv Prosthodont. 2010 Sep;2(3):111-5. doi:10.4047/jap.2010.2.3.111

5. Denry I, Kelly JR. State of art zirconia for dental applications. J Dent Mater. 2008Mar;24(3):299-307. doi:101016/j.dental.2007.05.007.

6. Culp L, McLaren EA. Lithium disilicate: the restorative material of multiple options. Compend Educ Dent. 2010 Nov-Dec;31(9):716-20,722,724-5.

7. Helvey G. Monolithic versus belayed restorations: A closer look. Inside Dentistry. 2010 Jul-Aug;3(2):16-23.

8. IPS e.max® lithium disilicate. The future of all-ceramic dentistry. Ivoclar Vivadent AG. www.ivoclarvivadent.com.

9. Koutayas SO, Vagkopoulou T, Pelekanos S, Koidis P, Strub JR. Zirconia in Dentistry: Part 2. Evidence-based clinical breakthrough. Eur JEsthet Dent. 2009 winter;4(4):348-80.

10. Hattab FN, Yassin OM. Etiology and diagnosis of tooth wear: a literature review and presentation of selected cases. Int J Prosthodont. 2000 Mar$\operatorname{Apr;13(2):101-7.~}$

11. Al-Omiri MK, Lamey PJ, Clifford T. Impact of tooth wear on daily living. Int J Prosthodont. 2006 Nov-Dec;19(6):601-5.

12. Mundhe K, Jain V,Pruthi G, Shah N. Clinical study to evaluate the wear of natural enamel antagonist to zirconia and metal ceramic crowns. JProsthet Dent. 2015 Sep;114(3):358-63. doi:10.1016/j.prosdent.2015.03.001.

13. Ceren N, Turp V, Emir F, Akgüngör, AyyildizS, Sen D. Nanoceramics and hybrid materials used in CAD/CAM systems. Dentayden J. 2016 Jan;2(3):55-62.

14. JiB, Alrayes AA, Zhao J, Feng Y, Shen Z. Grinding and polishing efficiency of a novel self-glazed zirconia versus the conventional dry-pressed and sintered zirconia ceramics. AAC J. 2018 May;118(1-2):46-55. doi: 10.1080/17436753.2018.1472904.

15. Ogura H, Kakuta K. Wear test of dental restorative materials. Japanese J Tribol. 2003 January; 48(6):551-8.
16. Yip KH Smales RJ, Kaidonis JA. Differential wear of teeth and restorative materials: clinical implications. Int J Prosthodont. 2004 May-Jun; 17(3):350-6.

17. Preis V, Behr M, Kolbeck C, Hahnel S, Handel G, Rosentritt M. Wear performance of substructure ceramics and veneering porcelains. Dent Mater. 2011Aug;27(8):796-804. doi:10.1016/j.dental.2011.04.001.

18. Amer R, Kürklü D, Johnston W. Effect of simulated mastication on the surface roughness of three ceramic systems. J Prosthet Dent. 2015 Aug;114(2):260-5. doi:10.1016/j.prosdent.2015.02.018.

19. Naumova EA, Schneider S, Arnold WH, Piwowarczyk A. Wear behavior of ceramic CAD/CAM crowns and natural Antagonists. J Mater.2017 Feb;10(3):244. doi:10.3390/ma10030244.

20. Shah S, Michelson C, Beck P,Ramp LC, D Cakir, JBurgess. Wear of enamel on polished and glazed zirconia [abstract].J DentRes. 2010 Mar;89(spec iss A) Abstract227.

21. Kontos L, Schille C, Schweizer E, Geis-Gerstorfer J. Influence of surface treatment on the wear of solid zirconia, Acta Odontol Scand. 2013 MayJul;71(3-4):482-7. doi:10.3109/0016357.2012.696690.

22. Giordano R, Sabrosa CE. Zirconia: material background and clinical application. Compend Contin Edu Dent. 2010 Nov-Dec;31(9): 710-5.

23. Stawarczyk B, Özcan M, SchmutzF, Trottmann A, Roos M, Hämmerle CH. Two-body wear of monolithic, veneered and glazed zirconia and their corresponding enamel antagonists. Acta Odontol Scand. 2013 Jan;71(1):102-12. doi: 10.3109/00016357.2011.654248.

24. Mitov G, Heintze SD, Walz S, Woll K, Muecklich F,PospiechP.Wear behavior of dental Y-TZP ceramic against natural enamel after different finishing procedures. J Dent Mater.2012 Aug;28(8):909-18. doi: 10.1016/j. dental.2012.04.010.

25. Hamza TA, Alameldin AA, Elkouedi AY, Wee AG. Effect of artificial accelerated aging on surface roughness and color stability of different ceramic restorations. Stomatological Dis Sci.2016 Dec;1:8-13. doi:10.20517/25730002.2016.05.

26. Sehgal M, Bhargava A, Gupta S, Gupta P. Shear bond strengths between three different yttria-stabilized zirconia dental materials and veneering ceramic and their susceptibility to autoclave induced low-temperature degradation. Int $\mathrm{J}$ Biomater.2016;8:1-7. doi:10.1155/2016/9658689.

27. Brown WS, Jacobs HR, Thompson RE. Thermal fatigue in teeth. JDent Res 1972 Mar-Apr;51(2):461-7. doi: 10.1177/00220345720510023601.

28. Mondelli RF, Wang L, Garcia FC, Prakki A, Mondelli J, Franco EB, Ishikiriama A. Evaluation of weight loss and surface roughness of compomers after simulated tooth-brushing abrasion test. J Appl Oral Sci. 2005 Jun;13(2):131-5. doi:10.1590/S1678-77572005000200007.

29. Lambrechts P,Debels E, Van LanduytK, Peumans M, Van Meerbeek B. How to simulate wear? Overview of existing methods. Dent Mater. 2006 Aug;22(8):693-701. doi:10.1016/j.dental.2006.02.004

30. Passos SP, de Freitas AP, lorgovan G, Rizkalla AS, Santos MJ, Santos Júnior GC. Enamel wear opposing different surface conditions of different CAD/ CAM ceramics. Quintessence Int. 2013 Nov-Dec;44(10):743-51. doi:10.3290/j. qi.a29750.

31. Magne P,Oh WS, Pintado MR, DeLong R. Wear of enamel and veneering ceramics after laboratory and chairside finishing procedures. J Prosthet Dent 1999Dec;82(6):669-79. doi: 10.1016/s0022-3913(99)70008-9.

32. Preis V, Weiser F, Handel G, RosentrittM. Wear performance of monolithic dental ceramics with different surface treatments. Quintessence Int. 2013 May;44(5):393-405. doi: 10.3290/j.qi.a29151.

33. IPS e.max®CAD. Scientific documentation. Ivoclar Vivadent AG. www. ivoclarvivadent.com 
34. IPS e.max®Ceram. Scientific documentation. Ivoclar Vivadent AG. www. ivoclarvivadent.com

35. ZirkonZahn®, human zirconium technology.Zirconia-Information for dentists FAQ's-from the dental practice. ZikonZahn worldwide-An der Ahr 7-39090 Gais/South Tirol (Italy). www.zirkonzahn.com

36. AlbashairehZS, Ghazal M, Kern M. Two-body wear of different ceramic materials opposed to zirconia ceramic. J ProsthetDent. 2010 Aug;104(2):105-13. doi:10.1016/S0022-3913(10)60102-3.

37. Miyazaki T,Nakamura T,Matsumura H,Ban S, Kobayashi T.Current status of zirconia restoration. JProsthodont Res. 20130ct;57(4):236-61. doi:10.1016/j. por.2013.09.001.

38. Kuretzky T,Urban M, Dittmann R, Peez R, Mecher E. Wear behavior of Zirconia compared to state-of-the-art ceramics. In: 89th IADR; 2011Mar;[Abstr. No. 1381].

39. Lawson NC, Janyavula S, Syklawer S, McLaren EA, Burgess J0. Wear of enamel opposing zirconia and lithium disilicate after adjustment, polishing and glazing. JDent. 2014 Dec;42(12):1586-91. doi:10.1016/j.ent.2014.09.008.

40. Mörmann WH,Stawarczyk B, Ender A, Sener B, Attin T, Mehl A. Wear characteristics of current aesthetic dental restorative CAD/CAM materials: two-body wear, gloss retention, roughness and Martens hardness. J Mech Behav Biomed Mater.2013 Apr;20:113-25. doi:101016/j.jmbbm.2013.01.003.

41. Alhabdan AA, El-Hejazi AA. Comparison of surface roughness of ceramics after polishing with different intraoral polishing systems using profilometer and SEM. J Dent Health Oral Disord Ther. 2015 May;2(3):1-11. doi:10.15406/ jdhodt.2015.02.00050.

42. Singh A, Sengupta B, Kuckreja H, Kuckkreja KBS. An in vitro study to compare glazed and polished surfaces of feldspathic porcelain and comparing three different polishing systems. Indian J Dent Sci. 2017 Sep;9(5):21-6. doi: 10.4103/ IJDS.IJDS 8717.

43. Saiki O, Koizumi H, Akazawa N, Kodaira A, Okamura K, Matsumura H. Wear characteristics of polished and glazed lithium disilicate ceramics opposed to three ceramic materials. J Oral Sci. 2016;58(1):117-23. doi: 10.2334/ josnusd.58.117.
44. Sarikaya I, Güler AU.Effects of different polishing techniques on the surface roughness of dental porcelains. J Appl Oral Sci. 2010 Jan-Feb;18(1):10-6. doi: 10.1590/s1678-77572010000100004.

45. Olivera AB, Matson E, Marques MM. The effect of glazed and polished ceramics on human enamel wear. Int J Proshtodont. 2006 NovDec;19(6):547-8.

46. Heintze SD, Cavalleri A, Forjanic M,Zellwege, Rousson V. Wear of ceramic and antagonist--a systematic evaluation of influencing factors in vitro. J Dent Mater.2008 Apr;24(4):433-49. doi:10.1016/j.dental.2007.06.016.

47. Jagger DC, Harrison A. An in vitro investigation into the wear effects of unglazed, glazed, and polished porcelain on human enamel. JProsthet Dent. 1994 Sep; 72(3):320-3. doi:101016/0022-3913(94)90347-6.

48. Alves LMM, Contreras LPC, Bueno MG, Campos TMB, Bresciani E, Valera MC Melo RM. The wear performance of glazed and polished full contour zirconia. Braz Dent J.2019 0ct:30(5):511-8. doi: 101590/0103-6440201902801

49. SuputtamongkolK, Anusavice KJ, Suchatlampong C, Sithiamnuai P, Tulapornchai C. Clinical performance and wear characteristics of veneered lithia-disilicate-based ceramic crowns. J Dent Mater.2008 May;24(5):667-73. doi: 10.1016/j.dental.2007.06.033.

50. Kim MJ,OHSH, Kim JH, Ju SW, Seo DG, Jun SH, Ahn JS, Ryu JJ. Wear evaluation of the human enamel opposing different Y-TZP dental ceramics and other porcelains. J Dent. 2012 Nov;40(11):979-88. doi:10.1016/j.dent.2012.08.004.

51. Esquivel-Upshaw JF, Young H, Jones J, Yang M, Anusavice KJ. In vivo wear of enamel by a lithia disilicate-based core ceramic used for posterior fixed partial dentures: first-year results. Int J Prosthodont. 2006 Jul-Aug;19(4):391-6.

52. Burgess J0, Janyavula S, Lawson NC, Lucas TJ, Cakir D. Enamel wear opposing polished and aged zirconia. Oper Dent. 2014 Mar-Apr;39(2):189-94. doi: 10.2341/12-345-L.

53. Arsecularatne JA, Dingeldein JP,Hoffman M. An in vitro study of the wear mechanism of a leucite glass dental ceramic. Biosurface and Biotribology. 2015 March;1(1):50-61. doi:10.1016/j.bsbt.2015.02.004

\section{Dina Kamal Abouelenien} (Corresponding address)

Teaching Assistant, Fixed Prosthodontics Department, Faculty of Oral and Dental Medicine, Misr International University, KM 28 Cairo - Ismailia Road Ahmed Orabi District, Postal Code 1, Cairo - Egypt. Date submitted: 2019 0ct 03 E-mail: dinakamaleldin@gmail.com Accept submission: 2020 Jan 07 